\title{
INFLUENCE OF ELEVATION ON HONEYBEES Apis mellifera syriaca (HYMENOPTERA: APIDAE) FLIGHT ACTIVITIES AND ITS IMPACT ON FRUIT SET AND QUALITY OF WATERMELON (Citrullus lanatus, CUCURBITACEAE)
}

\author{
Shahera Zaitoun $^{1 *}$ and Abd Al-Majeed Al-Ghzawi ${ }^{2}$ \\ 1, Department of Plant Production and Protection, Faculty of Agricultural Technology, Al-Balqa'Applied \\ University, Al-Salt, Jordan. \\ ${ }^{2}$ Department of Plant Production, Faculty of Agriculture, Jordan, University of Science and Technology, P. O. \\ Box 3030, Irbid, Jordan.
}

\begin{abstract}
A field experiment was conducted to monitor the flight activities of the worker bees of Apis mellifera syriaca and their impact on pollination of watermelon Citrullus lanatus as affected by the growing area elevations. The experiment composed of three treatments, the control (covered plants); in which the plants were caged before flowering to prevent any contact with insect pollinators, the second treatment the plants were left opened to permit contact with honeybees (uncovered plants) and the third treatment the plants were supplementary pollinated with pollen from other plant (hand pollination). The results of this experiment showed that the viability of female flower stigmas lasted mostly to the early hours of the day at 11:00 am for flowers produced in Madaba (780 m above sea level), and lasted to the afternoon of the day at 14:00 pm for flowers produced in Wadi Araba, Al Safi village (350 m below sea level). In general fruit set, seed set, number of fertile seeds, fruit weight, and fruit sugar content were significantly higher in uncovered followed by supplementary pollinated then covered plants while fruit length and fruit circumference were significantly higher in uncovered followed by covered and finally supplementary pollinated plants. Furthermore, fruit set, seed set, fruit weight, fruit circumference, and fruit total soluble solids percentage was significantly higher in plants grown above sea level than below sea level. Honey bees play an important role in the production of high quality and quantity of watermelon fruits for plants grown above or below sea level.
\end{abstract}

Keywords: Honey bees, Watermelon, Elevation, Pollination, Apis mellifera, Flight activity, Fruit set, Jordan

\section{INTRODUCTION}

Watermelon (Citrullus lanatus, Cucurbitaceae) is annual vining vegetable crop belongs to Cucurbitaceae family (Davis and Meinert 1965). It is one of the most common types of melon in Jordan. Watermelon planted during winter in the Jordan valley and during summer in the high lands and desert areas under open field irrigated conditions. Most vine crops produce both staminate and pistillate flowers separately on the same plant, the plants are referred to as being monoecious. Flowers of watermelon are staminate (male), perfect (hermaphroditic), or pistillate (female). Pistillate flowers have an inferior ovary, and the size and shape of the ovary is correlated with final fruit size and shape (Rubatzky and Yamaguchi, 1997). In many varieties, the pistillate or perfect flowers are born at every seventh node, with staminate flowers at the intervening nodes. However, the hermaphrodite flowers of watermelon do not pollinate themselves adequately without the aid of bees.

Using of honeybees in pollination of melons in commercial fields is well known and valued method (Bohart, 1970) Because honeybees can perform well

Corresponding Author: *Zait2010@yahoo.com, zaitoun@bau.edu.jo 
under diverse climatic conditions and multiplying their numbers in relatively short time; the colonies can be sited when and where its needed to satisfy pollination requirements (Mann, 1953). Cucurbit vegetable crops, such as watermelon require insect pollination for fruit set, which is usually achieved by placing honeybee (Apis mellifera) colonies in the field. Bees forage on cucurbit flowers for nectar and pollen grains that picked up from staminate flowers on the body hairs and rubbing off during successive visits to pistilate flowers (Mussen and Thorp, 1997). Many researches concentrated on the significant of using local race of honey bees Apis mellifera as pollinators in triploid watermelon (Stanghellini et al., 1998). Alan (2005a b) reported that the honeybees Apis mellifera races are important pollinators of triploid watermelon and female flowers require multiple honeybees or other wild bees visitations after visiting staminate (or male) flowers for pollination and fruit set and pollination. Also, increased number of bee visits for triploid watermelon had a strong positive effect on fruit set and yield (Stanghellini et al., 1998). Early pollination and subsequent fruit set will give rise to early harvesting and thus premium prices, particularly for the earlier melons cultivars. Melons produced from insect pollinated fields tended to be sweeter, larger and more uniform in size comparing with covered plants of no insect pollinators (Bodnar, 1987).

The roles of local race of honeybees Apis mellifera syriaca as pollinators for watermelon production under semiarid Mediterranean condition in Jordan are not yet evaluated. Apis mellifera syriaca, is a native bee in the east of Mediterranean region and one of the oldest honeybee races (Ruttner, 1988) and well adaptive to the local semiarid environmental conditions (Al-ghzawi et al., 2001; Zaitoun 2000; Zaitoun and Vorwohl, 2003). It has the capability to pollinate different flowers of fruit trees, medical plants and vegetable crops grown in Jordan (Zaitoun and Al-ghzawi, 2007; Zaitoun et al. 2008; Al-ghzawi et al., 2009 a b c; Zaitoun et al. 2009; Al-ghzawi et al., 2014 a b). Therefore; the main objectives of this study were to investigate the role of Syrian honeybees in pollination of watermelons grown under two different elevations at $780 \mathrm{~m}$ above sea level and at the lowest point of the world near the Dead Sea in Jordan. The role of the bees will be evaluated against covered treatment and hand pollinated treatment. Moreover different fruit and seed quality characteristics will be used as parameters for pollination efficiency and success.

\section{MATERIALS AND METHODS}

\section{Site description}

This experiment was conducted during 2012/2013 growing seasons at two different locations. The first one located in Madaba, $\left(31^{\circ} 43^{\prime \prime} \mathrm{N}, 35^{\circ} 48^{\prime \prime} \mathrm{E}\right.$ with 780 $\mathrm{m}$ above sea level). It characterized by semiarid Mediterranean condition with of mild rainy $(225 \mathrm{~mm})$ winters and dry hot summers. The second one located in Wadi Araba, Al Safi village near the Dead the lowest point in the world $\left(31^{\circ} 32^{\prime \prime} \mathrm{N}, 35^{\circ} 28^{\prime \prime} \mathrm{E}\right.$ with $350 \mathrm{~m}$ below sea level). As an average of the last 10 years, the area has a mild winters with a mean temperature of the coldest month (December) around $11^{\circ} \mathrm{C}$, warm summers with a mean warmest month temperature (July) around $42^{\circ} \mathrm{C}$. The rain period mainly during November to March months and the mean annual precipitation is $70 \mathrm{~mm}$.

\section{Bee colonies}

Four hives of Apis mellifera syriaca were introduced and placed at the field border at the beginning of the flowering stage. Each hive was established in a standard one-story with 10- frame Langstroth hive. The hives have similar number of worker bees, brood combs, stored food, and supplied continuously with water and protected from sunlight. All management practices including feeding, supering and swarm prevention was carried out. The same hives were used in both locations, that they were moved to the first location under sea level in October 2012 and migrated to the second location in April 2013.

\section{Experimental plant}

A commercial watermelon hybrid (Samara f1/SAKATA) was used in these experiments. Seeds were planted in trays containing peat moss in $1 / 11 / 2012$, for planting under sea level, and $1 / 3 / 2013$ for planting above sea level. In each location, three raised beds (blocks) were prepared and mulched with polyethylene plastic mulch after drip irrigation system has been installed. When transplants 
were reached the first true leaf stage, twelve transplants were transplanted into each treatment with $120 \mathrm{~cm}$ between plants.

\section{Pollination treatments}

For the pollination studies, three beds were randomly selected. Each bed contain twelve plants, it was divided into three pollination treatments: the control (covered plants); in which the plants were caged before flowering to prevent any contact with insect pollinators, the second treatment the plants were left opened to permit contact with honeybees (uncovered plants) and the third treatment the plants were supplementary pollinated with pollen from other plant (hand pollination). As usually, each plant has one fruit.

\section{Stigma receptivity}

To determine at which developmental stage flowers had receptive stigmata, 3\% hydrogen peroxide was placed on the stigma of flowers. Bubbles are produced when the mucus exuded by a receptive stigma contacts hydrogen peroxide (Dafni, 1992). Stigma viability was tested during pollination period by randomly a signing twenty four pistilate flowers from each covered and uncovered sub plot. Twelve flowers of from each treatment were freshly picked at half open growth stage at different time intervals within day, 8:00, 11:00, 14:00 and 17:00 o'clock. The other twelve flowers were picked the next day at opened stage on same previously assigned time of the day. A small drop of $3 \%$ hydrogen peroxide was applied to stigma which placed under dissecting microscope (Olympus optical company, Japan), waiting few minutes for the presence of a bubbling action as an indication of stigma viability.

\section{Data recording}

Fruits were harvested at August 2013 for first location and at April 2013 for the second location. Fruits length, circumference and weight for all treatments were recorded. Moreover, total numbers of seeds, fertile seeds and sterile seeds were recorded. Sugar content ( ${ }^{\circ}$ Brix) was estimated by refractometer (Fernando G., Own work).

\section{Statistical analyses}

This experiment was planed as Split-plot Randomized Complete Design (RCBD) with four-replications. The locations were assigned to main plots and the pollination treatments were assigned as subplots. Data were analyzed by analysis of variance (ANOVA) using SAS. Least Significant Differences (LSD) was used to comparisons between means of locations, treatments and interaction at 0.05 probability level.

\section{RESULTS}

In both experiments, the pollination treatments $\mathrm{x}$ locations interactions were significant at $(\mathrm{P} \leq 0.05)$. The main effect of pollination treatments and locations were significant for all fruit parameters shown in Table 1 and Table 2.

Location1 (Madaba, 780m above sea level) recorded higher average values with significant difference compared to Location2 (Wadi Araba, Al Safi village near the Dead Sea the lowest point in the world). Thus, in location 1 the average fruit length $(44 \mathrm{~cm})$ was higher than that for plants grown in location2 $(30.0 \mathrm{~cm})$

Concerning pollination treatments; fruits grown under open pollination were the longest $(62 \mathrm{~cm}$ and $40 \mathrm{~cm}$ ), followed by cover treatment $(40 \mathrm{~cm}$ and $30 \mathrm{~cm}$ ) and hand pollination $(30 \mathrm{~cm}$ and $20 \mathrm{~cm})$ for location 1 and location 2 respectively. Furthermore, fruit diameter in location $1(37 \mathrm{~cm})$ were superior to that grown in location $2(20.3 \mathrm{~cm})$.

Regarding pollination treatments open pollinated plants had the highest fruit diameter $(37 \mathrm{~cm}$ and26 $\mathrm{cm})$ followed by fruit under cover treatment $(32 \mathrm{~cm}$ and 19), fruit diameter were the lowest when plants were hand pollinated $(28 \mathrm{~cm}$ and $16 \mathrm{~cm})$ for location 1 and location 2 respectively.

Significant differences were recorded for fruit weight at $(\mathrm{P} \leq 0.05)$ among location and pollination treatments (Table 1) Fruit weight in location 1 (7.4kg) were higher than that grown in location2 $(4.3 \mathrm{~kg})$. Moreover, the pollination treatments $\mathrm{x}$ locations interaction were also significant at $(\mathrm{P} \leq 0.05)$. Furthermore, the cover treatment fruit weight recorded the lowest values $(3 \mathrm{~kg}$ and $1.2 \mathrm{~kg}$ ) 
compared with the hand pollination treatment $(4.4 \mathrm{~kg}$ and $7.4 \mathrm{~kg}$ ) and open pollination recorded the highest values $(10.2 \mathrm{~kg}$ and $7.4 \mathrm{~kg})$ for location 1 and location 2 respectively.

Sugar content was also affected significantly by location and pollination treatments, fruits grown in location 1 had higher sugar content value $\left(13.6{ }^{0} \mathrm{Brix}\right)$ than that grown in location $2\left(7.1{ }^{0}\right.$ Brix $)$. In addition, fruit grown under open pollination treatment had higher sugar content (19 and $10{ }^{0}$ Brix) followed by hand pollination (14 and $\left.7{ }^{0} \mathrm{Brix}\right)$ and the least was cover treatment ( 8 and $4.5{ }^{0}$ Brix) for location 1 and location 2 respectively.

Table 2 shows significant difference in all seeds parameters between pollination treatments and locations at $(\mathrm{P} \leq 0.05)$, pollination treatments $\mathrm{x}$ locations interaction were significant in the two experiments. Fruit grown in location 1 produced higher seeds number per fruit (268 seeds) than that grown in location2 (98.3 seeds). Fruit grown under open pollination produced (313) seeds per fruit, followed by hand pollination (142) seeds per fruit and fruit under cover treatment (94) seeds per fruit.

Moreover, in location 1 fruit produced in average (220 fertile seed per fruit) higher than that grown in location2 (74.3 fertile seeds per fruit). Also, fruit grown under open pollination had produced higher fertile seeds per fruit (294), followed by hand pollination (124.5) and cover treatment (23.5). Moreover, fruit grown in location 1 produced (47 sterile seeds per fruit) higher than that grown in location2 (24 sterile seeds per fruit) and cover treatment produced higher sterile seeds per fruit than other pollination treatments.

The results showed that the viability of female flower stigmas lasted mostly to the early hours of the day at 11:00 am for flowers produced in Madaba $(780 \mathrm{~m}$ above sea level), and lasted to the afternoon of the day at 14:00 pm for flowers produced in Wadi Araba, Al Safi village (350 $\mathrm{m}$ below sea level).

\section{DISCUSSION}

The present experiments proved that Apis mellifera syriaca is efficient pollinator of Citrullus lanatus. Watermelon like other Cucurbitaceae requires insect vectors such as honeybees to increase fruit set and yield quality. This result agrees with many researchers who found that honeybees are important pollinator of triploid watermelon (Alan, 2005a b; Stanghellini et al., 1998) and of muskmelon (AlGhzawi et al., 2007; Bohn and Mann, 1960). Honeybees increase yield mainly by increasing fruit number, fruit set and decreasing abortion rate (Alan, 2005 a b; Stanghellini et al., 1998). Alan (2005 a) reported that the increase in fruit set rate by honeybees under open pollination treatment $80 \%$ compared with plants under cover treatment, this result may be attributed to presence of honeybees lead to decrease abortion rate in watermelon. Moreover, the same result was recorded in other cucurbitaceous like muskmelon (Al-Ghzawi et al., 2007; Bohn and Mann 1960). It seems that honeybees are not only successful in pollination process itself but also transfer viable high quality pollen grains which affect positively post pollinationprocess. Stephenson (1981) and Lee (1988) mentioned that fruit-set among flowers within inflorescences is not influenced only by pollination success but also by post-pollination processes such as variation in the quality of pollen arriving at flowers, pollen germination activity, pollen tube growth, and development of fertilized seeds. Also, fruit set is influenced by the time of flowering during the different months of the year.

In addition, this study showed that elevation seems to play role in pollination process success; fruit length, circumference, weight, number of seeds per fruit, number of fertile seeds per fruit and fruit sugar content were higher at $780 \mathrm{~m}$ above sea level (location1) compared to the second location at the lowest point of the world (location2). Since studies about elevation effect on pollination is rare, it's difficult to compare our results with others. Further work should be done to explore pollination elevation relation.

Fruit length and fruit circumference were higher in open pollination treatment followed by covered treatment and the least were recorded in hand pollination treatment in both elevations. But, fruit weight, number of seeds per fruit, number of fertile seeds per fruit and fruit sugar content were the highest under open treatment followed by hand pollination treatment and then cover treatment. Sterile 
seeds recorded the highest value in the cover treatment and the least in the open treatment. These results in agreement with other researchers, Alan (2005 a) and Stanghellini et al. (1998) they reported that the fruit weight and number increased under open pollination than that under low or no visitation, also lead to increase fruit yield per hectare. Bodnar (1987) reported that muskmelons produced from insect pollinated fields tended to be sweeter, larger and more uniform in size comparing with covered plants of no insect pollinators. Stanghellini et al. (1998) detected high positive correlation between seed number and fruit size of muskmelon Also, strong correlation between presence of honeybees and muskmelon yield were registered (Al-Ghzawi et al.; 2007; Bohn and Mann 1960). These results may attributed to efficient pollinators (honeybees) leading to large number of pollen grains transfer to stigmas of pistilate flowers causing high percentage of fruit setting (Bodnar, 1987), or result of increases in growth and development in the ovary then increase in fruit size after fertilization (Rubatzky and Yamaguchi, 1997).

In this study fruit weight was higher in uncovered fruits than covered plants with significant differences. This proves again the positive pollination effects of honeybees. It is known that Increasing in fruit size related usually to fertilization, and sometimes to pollination alone, by stimulating the floral parts causing a rapid cell division that leads to differentiation of fruit parts, and trigger fruit growth by hormone production (McGregor S. E. 1976). Other factor play a role in the size and weight of fruit are the size and number of seeds produced in the fruit. Reduction of seed size and number reduces fruit size (Mizrahi et al., 1997) Also; Low fruit weight compared to the large fruit size in cover treatment of this study can be explained on the base of poor seed set as discussed by Jones et al. (1998).

In addition, sugar content was affected by pollination treatments, i.e. sugar content was higher under open pollination treatment then hand pollination treatment compared to cover treatment this agrees with findings in other cucurbits; Bodnar (1987) reported that muskmelon produced from insect pollinated fields tended to be sweeter, larger and more uniform in size comparing with covered plants of no insect pollination.. Denney (1992) mentioned that the taste qualities and soluble solids accumulation that contain mainly sugars may be explained by seed - controlled hormonal level

In conclusion, honeybees Apis mellifera syriaca and elevation from sea level are playing significant role in pollination and yield of watermelon grown under semiarid conditions, this role should be enhanced to ensure higher visitation rates to watermelon flowers. Studies concerning pollination of watermelon and factors affecting it are very scarce. Further studies should be made to explore the role of honeybees in pollination of Citrullus lanatus in order to get high quantity and quality yield.

\section{REFEENCES}

Alan W. S a. (2005). Honey Bee Pollination Requirements for Triploid Watermelon. HortScience 40: 1268-1270.

Alan W. S S b. (2005). Influence of Honey Bee Pollination on Triploid Watermelon Fruit Set and Quality. HortScience 40: 993-1147.

Al-Ghzawi, A.; Zaitoun S. and Shannag H. . 2001. Seasonal cycles of Apis mellifera syriaca under Jordanian desert conditions. Journal of Apicultural Research. 40(2): 45-51.

Al-Ghzawi A.; Zaitoun S.; and Hajeer Y. 2007. The role of honey bee Apis mellifera syriaca in pollination of four muskmelon (Cucumis melo) cultivars grown under semiarid conditions. Advances in Horticultural Science 21(1): 41-46.

Al-Ghzawi A. and Zaitoun S. Al-qudah A. and Ghosheh H. 2009a. Impacts of Drought on Pollination of Trigonella moabitica (Fabaceae) via bee Visitations. Archives of Agronomy and Soil Science.55 (6):683-692.

Al-ghzawi A.; Samarah N.; Zaitoun S. and Alqudah A. 2009b. Impact of bee pollinators on seed set and yield of Vicia villosa spp. dasycarpa (Leguminosae) grown under semiarid conditions. Italian Journal of Animal Science. 8: $65-74$

Al-Ghzawi A.; Zaitoun S. and Samarah N. 2009c. The impact of bee colony distance and racemes order on pollination of Prosopis juliflora in the Jordan Valley. Advances in Horticultural Science 23 (2): 81-86.

Al-ghzawi A.; Zaitoun S. Freihat N. and Al-Qudah A. 2009. Effect of pollination on seed set of Origanum syriacum under semiarid Mediterranean conditions. Acta Agriculturae Scandinavica 59 (3): 273-278.

Al-ghzawi A., Zaitoun S. and Alwedyan M. 2014. The impact of honeybee visitations on pod and seed set of carob trees Ceratonia siliqua. American-Eurasian Journal of Sustainable Agriculture. 8(12): 49-55.

Bodnar J. 1987. Pollination of Vine Crops. Fact sheetISSN 1198-712X. Government of Ontario. Ministry of Agriculture, Food and Rural Affairs. Ontario. USA.

Bohart G. E. 1970. Management of wild bees for the pollination of crops. Entomology Research Division, 
Agriculture Service, U.S. Department of Agriculture, Logon Utah. Pp. 287-312.

Bohn G. W. and L. K. Mann. 1960. Nectarless, a yeildreducing mutant character in the muskmelon. Amer. Soc. Hort. Sci. Proc. 76: 455-459.

Dafni A., 1992. Pollination ecology. Oxford University Press Inc.,Oxford, UK.

Davis, G.N. and U.G.H. Meinert. 1965. The effect of plant spacing and fruit pruning on the fruits of PMR No. 45 Cantaloupe. Proc. Amer. Soc. Hort.Sci. 87:299-302.

Denney, J.O. 1992. Xenia includes metaxenia. Hort. Science, 27:722-728.

Jones T., Rowell B.,Strang J., Bessin R. and Nesmith B.1998. Pumpkin integrated pest management. IPM 12 Grower manual. Kentucky.USA.

Lee, T.D., 1988. Patterns of fruit and seed production. In J. Lovett Doust and L. Lovett Doust [eds.], Plant reproductive ecology: patterns and strategies, 179-202. Oxford University Press, New York, New York, USA.

Mann, L.K. 1953. 'Honey Bee Activity in Relation to Pollination and Fruit Set in the Cantaloupe (Cucumis melo). American Journal of Botany, 40: 545-553.

McGregor S. E. 1976. Insect pollination of cultivated crop plants. Agric. Handbook. U.S. Dep. Agric. No. 496. United States. Pp. 411

Mizrahi Y.; A. Nerd and P. Nobel. 1997. Cacti as crops. Horticultural Review 18: 29 -320.

Mussen C. E., Thorp W.R., 1997. Honey bee pollination ofcantaloupe, cucumber, and watermelon.-Division of Agricul- ture and Natural Resources, University of California, Califor- nia, USA, Publication no. 7224

Percival M. S. 1961. Types of nectar in Angiosperms. New Phytologist 60(3):235-281.
Rubatzky V. E and Yamaguchi M. (1997). World vegetables, 2nd ed. Champan \& Hall Publ., New York.

Ruttner F. 1988. Biogeography and Taxonomy of Honeybees. Springer-Verlag, Berlin, pp 187-188.

Stanghellini M.S; Ambrose J.T and Schultheis J.R. (1998). Using Commercial Bumble Bee Colonies as Backup Pollinators for Honey Bees to Produce Cucumbers and Watermelons. HortTechnology 8: 464-626.

Stephenson, A.G., 1981. Flower and fruit abortion: proximate causes and ultimate functions. Annual Review of Ecology and Systematic 12: 253-279.

Zaitoun S. and Vorwohl G. 2003. Major Pollen Plant Species in Relation to Honeybees Activity in the Jordanian desert Area. International Journal of Agriculture and Biology 5(4): 411-415.

Zaitoun S. and Al-ghzawi A. 2007. Bee pollination and fruit set of Sumac (Rhus coriaria, Anacardiaceae) as a native herbal plant grown under semiarid Mediterranean conditions in Jordan. Advances in Horticultural Sciences 21(3): 183-187.

Zaitoun S., Al-ghzawi A. and Al -Qudah A. 2008. Comparative study in seed yield and flowers attractivity to bee visitors between Nigella sativa $L$. and Nigella damascena L. (Ranunculaceae) grown under semiarid conditions. 2008. Italian Journal of Agronomy. 2:125-130.

Zaitoun S., Al-ghzawi A., Samarah N. and Mullen R. 2009. Pod production of Prosopis juliflora (Sw.) DC. as affected by supplementary and honeybee pollination under arid conditions. Acta Agriculturae Scandinavica. 59 (4)349 356.

Zaitoun, S. T. 2000. Population dynamics of the Syrian Honeybee, Apis mellifera syriaca, under semi-arid Mediterranean conditions. The Seventh IBRA Conference on Tropical Bees: Management and Diversity. 19-26 March 2000. Chiang Mai, Thailand. 319-321. 


\section{APPENDIX}

Table 1: Length, diameter, weight and OBrix of watermelon fruit under all pollination treatments.

$†$ 1, 2,3, Fisher's Least Significantly Difference to compare between location means, treatment means, or treatment $x$ location interaction.

\begin{tabular}{|c|c|c|c|c|c|}
\hline \multirow[t]{2}{*}{ Location } & \multirow[b]{2}{*}{ Treatments } & \multicolumn{4}{|c|}{ Parameter } \\
\hline & & $\begin{array}{l}\text { Length } \\
\mathrm{cm}\end{array}$ & $\begin{array}{l}\text { Diameter } \\
\mathrm{cm}\end{array}$ & $\begin{array}{l}\text { Weight } \\
\mathrm{kg}\end{array}$ & ${ }^{0}$ Brix \\
\hline \multicolumn{6}{|l|}{ Location 1} \\
\hline & Open & $62 \mathrm{a}$ & $37 a$ & $13.0 \mathrm{a}$ & $19.0 \mathrm{a}$ \\
\hline & Cover & $40 \mathrm{~b}$ & $32 b$ & $3.0 \mathrm{c}$ & $8.0 \mathrm{c}$ \\
\hline & Hand pollination & $30 \mathrm{c}$ & $28 \mathrm{c}$ & $6.2 \mathrm{~b}$ & $14.0 \mathrm{~b}$ \\
\hline \multicolumn{6}{|l|}{ Location 2} \\
\hline & Open & $40 \mathrm{a}$ & $26 a$ & $7.4 \mathrm{a}$ & $10.0 \mathrm{a}$ \\
\hline & Cover & $30 \mathrm{~b}$ & $19 b$ & $1.2 \mathrm{c}$ & $4.5 \mathrm{c}$ \\
\hline & Hand pollination & $20 \mathrm{c}$ & $16 \mathrm{c}$ & $4.4 \mathrm{~b}$ & $7.0 \mathrm{~b}$ \\
\hline \multicolumn{6}{|l|}{ Main effects } \\
\hline & Location 1 & $44 \mathrm{a}$ & $32 \mathrm{a}$ & $7.4 \mathrm{a}$ & $13.6 \mathrm{a}$ \\
\hline & Location 2 & $30 \mathrm{~b}$ & $19 b$ & $4.3 b$ & $7.1 \mathrm{~b}$ \\
\hline & Open & $51 \mathrm{a}$ & $31 \mathrm{a}$ & $10.2 \mathrm{a}$ & $14.5 \mathrm{a}$ \\
\hline & Cover & $35 \mathrm{~b}$ & $25 b$ & $2.1 \mathrm{c}$ & $6.3 \mathrm{c}$ \\
\hline & Hand pollination & $25 \mathrm{c}$ & $21 \mathrm{c}$ & $5.3 b$ & $10.5 b$ \\
\hline $\operatorname{LSD}(0.05)^{1}$ & & 2.2 & 1.0 & 0.4 & 0.5 \\
\hline $\operatorname{LSD}(0.05)^{2}$ & & 1.2 & 1.1 & 0.3 & 0.7 \\
\hline $\operatorname{LSD}(0.05)^{3}$ & & 1.6 & 1.3 & 0.5 & 0.7 \\
\hline
\end{tabular}


Table 2: Effects of pollination treatments on seeds of watermelon grown at two different locations and as affected by pollination treatments.

$\dagger$ 1, 2,3, Fisher's Least Significantly Difference to compare between location means, treatment means, or treatment $x$ location interaction.

\begin{tabular}{|c|c|c|c|c|}
\hline \multirow[t]{2}{*}{ Location } & \multirow[b]{2}{*}{ Treatments } & \multicolumn{3}{|l|}{ Parameter } \\
\hline & & Seeds number & Fertile seeds & unfertile seeds \\
\hline \multicolumn{5}{|l|}{ Location 1} \\
\hline & Open & 471.0 & 451.0 & 20.0 \\
\hline & Hand pollination & 193.0 & 174.0 & 19.0 \\
\hline & Cover & 138.0 & 36.0 & 102.0 \\
\hline \multicolumn{5}{|l|}{ Location 2} \\
\hline & Open & 155.0 & 137.0 & 18.0 \\
\hline & Hand pollination & 91.0 & 75.0 & 16.0 \\
\hline & Cover & 49.0 & 11.0 & 38.0 \\
\hline \multicolumn{5}{|l|}{ Main effects } \\
\hline & Location 1 & 268.0 & 220.3 & 47.0 \\
\hline & Location 2 & 98.3 & 74.3 & 24.0 \\
\hline & Open & 313.0 & 294.0 & 19.0 \\
\hline & Hand pollination & 142.5 & 124.5 & 17.5 \\
\hline & Cover & 94.0 & 23.5 & 70.0 \\
\hline $\operatorname{LSD}(0.05)^{1}$ & & 9.2 & 9.3 & 4.3 \\
\hline $\operatorname{LSD}(0.05)^{2}$ & & 8.0 & 8.9 & 4.2 \\
\hline $\operatorname{LSD}(0.05)^{3}$ & & 2.4 & 2.6 & 2.6 \\
\hline
\end{tabular}

